\title{
The Demand of Local Based SPA Products Ingrediens in Several Major SPA Destinations in Bali
}

\author{
Komang Shanty Muni Parwati \\ Department of Tourism Management \\ Sekolah Tinggi Pariwisata Bali Internasional \\ Denpasar, Indonesia \\ komang.shanty@yahoo.com
}

\begin{abstract}
The Spa industry has been influencing the development of the hospitality industry in Bali for more than a decade. Spa facilities in Bali accommodate a variety of Spa service demands that are inspired by the local culture. These offer comfort, relaxation, luxury and stress-free, with the traditional touch of massage techniques for people who want to enjoy spas in Bali. One of the additional benefits comes from the use of local ingredients as the basis of spa products. The grand idea is to support local industries as well as offering a traditional essence for the spa customers. This study aims to describe the demand/popularity of local ingredients of spa products in several major spa destinations in Bali. The research uses a descriptivequantitative approach by describing data gathered from questionnaires and observation sheets from several major spa destinations in Bali. The result shows that, 1) $90 \%$ of the spas are using local ingredients in their products, 2) those highly demanded local products are chosen because of their perceived exoticism and nature compared to non-local products, 3 ) the most demanded basic ingredients of the spa products is coconut oil, chosen due to its healing benefits especially for the skin and hair. By the results of the research it can be concluded that local ingredients have their own special trade for the spa customers because of its exoticism and benefits obtained, as well as it can help the development of local industries. Hopefully, the use of local ingredients can be maintained and able to penetrate a broader market.
\end{abstract}

Keywords-Demand, Popularity, Local ingredients, SPA products, SPA Destination

\section{INTRODUCTION}

As part of the vast Indonesian archipelago, Bali has a rich art scene and a vibrant culture life and attracts of million visitors each year, both national and international visitors (Putra:2014). This touristic island become the most destination visitors to spend their holiday and to have some activities like touring across the island, enjoying the nature, marine-based tourist activities, having and spending time for Balinese art as well the culture, including having SPA.

As the home to some 300 spas, in 2009, Bali was awarded as the best spa destination, which makes it highly recommended for SPA fans to visit the island. Trying some of Balinese interesting spa treatments and products is necessary to complete the spa guest's experience.
Mainly the SPAS in Bali offer the traditional massages as treatments and using the local product for its. The body massage treatment is attracted tourist to relieve stress. SPA becomes the favorite place to fulfill the guest need for being stress-free, and pampering during enjoying the SPA time in their holidays.

SPA fans are a potential market for big and small businesses, self or private, corporate and society-based business that are growing in Bali, especially in tourist areas. Overall, the SPA business has grown rapidly with high competition from each spa destination in Bali. The local authorities have already seen the spa potential as means to improving the economy, employment, supplier spa products business. It is necessary to have the right regulation so this business is able to grow as sustainable tourism attraction which is environment friendly and able to increase the host community participation and host community welfare. The host community participate is the main factor to maintain the sustainable (Ariani:2011)

Several spas offer their uniqueness and signature treatments or products. Spas compared to those offered in the day spas in the towns, thus are able to attract newcomer spa tourists, spa in touristic area mostly offer their products based on herbal products. Since the rapid of business in the spa, the demand of the products and the unique treatments are wide. The modern, traditional, or mix concept of spa are being offered to attract the tourists needs.

Herbal medicines and massage are traditional methods that used by local healers for being health. Massage is a healing touch; it is a means of preventive medicine to relieve stress and maintain general good health in terms of relaxing treatments (Tilaar, 2008). For SPA- goers in Bali, trying Balinese massage or using local products in a small selection of SPA seems to be enjoyed by many visitors. And another thing is that it takes personal experience to enjoy the benefits of the local products. You haven't yet had the full "Bali SPA Experience" without doing so.

Spa can be announced as health and beauty center, and have strong traditional culture influences. Balinese traditional herbal medicine has been handed down from generation to generation, some are written on the coconut leaf books, or well known as Usada Lontar (Tilaar, 2008). 
The local products used for spa treatments in Bali are unique especially with health and beauty benefits. The tourists will find many similar products throughout many tropical and sub-tropical SPAs in Asia. However, since Bali is very popular as a major SPA destination visitors will also have the benefit of the local products that are available here.

The ingredients as base of the spas products of the Balinese traditional medicine are easy to find, prepare, and apply. They mainly consist of herbs, roots, minerals, and rare extract of animals/insects, as well as some other materials. In general, they are ground up or grated to make a paste, or boiled to distil them. The traditional use of plants and other ingredients are believed to provide a cure for many illnesses. These plants can be used individually as medicine or food, and although some may have multiple uses.

The local Balinese products for SPA have been used to complete the benefits of treatments. For massage, specially blended oils are used, and it based on coconut oil. Each treatment has its own local ingredients in a certain spa product and each having a variety of benefits.

This research aimed to describe the use of local ingredients of spa products in terms of its demand in several major spa destinations in Bali.

\section{LITERATURE REVIEW}

According to the Whelan \& Msefer (1997), demand is how often or how frequently the consumers want to buy or to get a product. They add theoretically in economy, the demand has taste and the ability to buy. The demand of using local product can increase the revenue and diversity the local economy, preservation of culture and preserved the environment (Hamzah, 2009). Tourist can help the local society to pay attention and aware of the values of their local products.

Demand is related to the popularity. Popularity is the state of being liked, enjoyed, accepted, or done by large number or people (Merriam-Webster). The traditional Balinese massage is well known as a favorite massage treatment in SPA world. It influences the product for the massage, and the popularity of traditional Balinese massage and the products can be shown in SPA menu treatments in all over spa (Lee \& Lim, 2008).

Traditional spa products are the traditional and natural products that made using traditional wisdom and include the selection, mixture, preparation and use of tonics, therapeutic massages and freshly picked medicinal plants and herbs (Skilkkerveer in Tilaar, 2008). Indonesian medical plants can make a major contribution to world health, and tourism industry can provide the better marketing to spread it.

Direct interaction between tourists and the local host communities can help tourist to understand and maintain the local culture as well the local knowledge. The cultural experienced by tourists will enriched the social understanding, so the social needs, environment and economy of local host are met through the supply of tourists' products (Goodwin: 2009). It will create the sustainable tourism, as tool in the local economic development and poverty reduction (Ray, 2015)
Spa as the health and beauty center provide and using the local ingredients for their treatments. With the traditional use of plants and other ingredients, the products for treatments are applied to developing rejuvenating new treatments within spa's today the traditional massage as popular treatment is using massage oil, made from coconut oil. The coconut oil prepared with local flowers such as champak, akar wangi (veviter) and pandanus leaf helps the recipient to reduce the stress and help the healing process. Cold pressed coconut oil lasts longer and has multiple positive effects on health. Softening dry skin, aiding digestion, reducing cholesterol, are some of the benefits and it is the main reasons for using coconut oils as SPA products (Tilaar, 2008).

\section{RESEARCH METHOD}

This study uses a mixed methods approach. In this method, the researchers are the primary means for collecting data through questionnaires, field observation, and in-depth interview with selected informants in SPA industries.

Questionnaires were distributed through structured list of questions sheet to respondents. Observation was done directly and non-directly, from researcher to the object research. The data obtained in the field, in the real situation and natural setting. The sample in this study comes from a purposive sampling method. The raw data are processed into understandable and informative data. Literature and the result were analyzed using descriptive qualitative interpretative method.

The variables that were analyzed in this research, among others: (1) the based ingredients for the spa treatments and products, (2) demand of local products, (3) the most demanded local ingredients.

\section{THE OVERVIEW OF RESEARCH LOCATION}

The research locations are in Sanur, Nusa Dua and Ubud. Sanur area is known as friendly environment. It is a favorite tourist area for local people and foreign tourists. Local spas, hotel and spa, resort and spa are having a good business in this area. The spas in Sanur area offer many treatments and using the mix products. Nusa Dua is also known as five stars hotels, resort and luxurious villas. This area is famous as a center for mice activities in Bali. The spa managed by hotels, resorts, villas and boutique hotels are helping the spa fans enjoying the facilities, memorable spa treatments and great spas products. The Ubud as the center of cultural attraction in Bali, and becomes a place for spa destination. Many luxurious spa in the resort or villas, the local spa with traditional treatments, are having potential spa markets. Spa goers are coming to trying the spa treatments and helping the yoga community growth in this beautiful area.

\section{RESULT AND DISCUSSION}

The data were obtained from 20 small, medium, luxury spas in Sanur, Nusa Dua and Ubud as major spa destinations in Bali. In order to obtain primary data, researcher conducted field research through distribution of questionnaires, where written 
questions were presented directly to the respondents. This was followed by interview and direct observation.

Spa products are available with various types and variations. The spa products are made from tropical plants, and commonly used in the preparation of local traditional medicine. Roughly half the ingredients in any Indonesian dish are also used in traditional medicine cures. Most of the therapists offer traditional Balinese massage, and it is announced as the signature massage in several spas. The contributions of coconut oil use, from and to the spa products, are widely used.

There are changes to the meaning of local product in the spa business, the local products have their own fans, and it can help their product to reach potential customers. In addition, local spa therapists need attract the potential local consumers with a very high quality product, to target local tourists with an internal competition. Based on the perception of the tourist, they will get a clear idea about the spa products if the spa therapist can explain the product and the benefits from each product's ingredients, fluently and specifically.

From the interview it is found out the SPA tourists consider aspects of opportunities for them to enjoy treatments based on local tradition. The people are choosing SPAs as one of their favorite places to visit on their list of "things to do in Bali" and, as such, it has become one of the most important choices to enjoy during vacations.

Furthermore, there are basically three findings of this research, which will be discussed on the following section. Firstly, local SPAs are using nearly $90 \%$ of local ingredients in their spa products. Based on observations made in several SPAs in area of Sanur, Nusa Dua, Ubud and Kuta, it was found out that local products are widely used as spa ingredients. Researched Spa are located in touristic areas, where the visitors are on average $65 \%$ of foreigners and $25 \%$ of domestic tourists, and the rest are local tourists of Bali who come to visit the places during their holidays.

From the survey conducted with therapists using interview method, it can be concluded that the spa visitors choose shades of traditional treatments such as traditional Balinese massage, a massage with traditional techniques in certain parts of the body like the back, arms and legs. Generally for the massage, local basic ingredients used in the spa products are oils, especially coconut oil.

The use of local materials for spa product like coconuts oil to massage is very common in the spa. Utilization of local ingredients can support the local product in the spa market. Instead of using the commercials products from overseas, using the local products with local ingredients will help the local producers as well as other supporting business.

Treatment massage is also the most frequent treatment offered in packages. In a care package in the SPA, in addition to offering massage, is also offered scrub treatment equipped with a shower of flowers to the body or head as a complementary treatment. In doing such scrub treatments, the basic materials used are a paste of rice, coconut oil, salt, and coffee.
The secondly findings, Local Spa products are highly in a choice because of the perception of exoticism by foreign tourists, and because of their properties compared to non-local products. Local products become the first choice of tourists, more for reasons that they are exotic memorable products, matched with the temperature and the current state of their vacation, considering Bali as a tropical island with tropical plants. The products are being produced along the line of treatment.

The last one is that the basic ingredients of the most demanded and popular spa product is coconut oil. Coconut oil is generally used because it has been proven to be beneficial for maintaining health and beauty. Coconut oil is often applied for skin and hair. This oil is used throughout Indonesia and has many uses. Coconuts grow along most of the coasts of the islands in Indonesia, and have long been used as food ingredients in Indonesian kitchens. In the field of beauty, traditionally, it has been used to cope with dry skin, rubbed into the skin by Indonesian women to maintain their beauty. Coconut oil is also used for hair, making hair easy to set up, maintaining its lustrous looks. For health reasons, oil is preferred for massage purpose.

\section{CONCLUSION}

From the results of the research it can be concluded that local ingredients have their own special niche in the competition for spa customers because of its perceived exoticism and benefits to be obtained by their use, also it can help the development of local industries. Hopefully, the use of local ingredients can be maintained and be able to penetrate a wider market. The spa business continues to grow, and it will give benefit to the local people if the business sustain. It will provide a good economic impact.

The products used should be standardized. The good quality of local products, interesting marketing, attractive packaging, and with a wide range of products available, will encourage these products to be chosen for spa-goers to use throughout the world.

\section{REFERENCES}

Ariani, Ni Made (2011). Partirispasi Hotel Melalui Friend of Community Hotel di Kabupaten Badung. Jurnal Ilmiah Pariwisata.Vol.1 No.02 Juli 2011. Bali. Indonesia.

Goodwin, Harold \& Santili, Rosa. (2009). Community- Based Tourism: A Success? In ICRT Occasional Paper 11. GZT German Development Agency.

Hamzah, Amran \& Zainab Khalifah. (2009). Handbook on Community Based Tourism: How to Develop and Sustain CBT. Singapore: APEC

Lee, Ginger \& Lim, Christine Zita. (2002). $\quad$ Acrhipelego Press. Singapore

Putra, I Wayan Dharma \& Campbell, Siobhan. (2015). Recent Developments in Bali Tourism. Bali. Indonesia.

Ray, Nilajan. (2015). Emerging Innovative Marketing Strategies in the Tourism Industry. USA: Business Science Reference. 
Tilaar, Martha.( 2008). Bali Shui-Pani-Amerta, secret of

Holistic on the island of the Gods. Copyright (C1994 by

Martha Tilaar. Saritaksu Editions. Bali. Indonesia.

Whelan, Joseph \& Msefer, Kamil. (1996). Economic Supply

\& Demand. Prepared for the MIT System Dynamics

in Education Project. Retrieved from

https://ocw.mit.edu/courses/sloan-school-of-

management/15-988-system-dynamics-self-study-fall1998-spring-1999/readings/economics.pdf on 0ct, 2.

2016. 